\title{
Phytoplankton depletion in the benthic boundary layer caused by suspension-feeding Nereis diversicolor (Polychaeta): grazing impact and effect of temperature
}

\author{
Anders Vedel* \\ Institute of Biology, Odense University, Campusvej 55, DK-5230 Odense M, Denmark
}

\begin{abstract}
Mesocosm and field studies were conducted to examine phytoplankton depletion in benthic boundary layers caused by suspension-feeding Nereis diversicolor populations at different temperatures. It was demonstrated that the ability of the worms to deplete the bottom water of phytoplankton was highly correlated with temperature dependent filtration and water pumping capacity. At the optimum temperature of $17.8^{\circ} \mathrm{C}$, the worm population $\left(57 \mathrm{~g} \mathrm{~m}^{-2}\right.$ dry wt) was able to deplete the water column of phytoplankton to a maximum height of $26 \mathrm{~cm}$, in unstirred water. The height of the algal depleted layer was controlled by a combination of the clearance capacity of the worms and the strength of vertical water mixing generated by the water jets ejected from the worm tubes. The algal concentration in the boundary layer was reduced from the initial 7000 to 10000 Rhodomonas cells ml $\mathrm{ml}^{-1}$ to a minimum of 1500 to 3000 cells ml ${ }^{-1}$ within 2 to $4 \mathrm{~h}$. In the field, the maximum height of the phytoplankton depleted zone was only 4 to $8 \mathrm{~cm}$, but considerable $(25$ to $40 \%$ ) phytoplankton depletion occurred in the bottom layer, even at moderate to high wind speeds $\left(6\right.$ to $8 \mathrm{~m} \mathrm{~s}^{-1}$ ). Wind speeds were less than $8 \mathrm{~m} \mathrm{~s}^{-1}$ for approximately $70 \%$ of the season (March to August 1995) and thus algal depletion above dense populations of suspension-feeding $N$. diversicolor may occur frequently in the shallow Odense Fjord, Denmark. Due to the presence of an algal depleted boundary layer, $N$ diversicolor was not able to control phytoplankton biomass at the field site in Odense Fjord, in spite of a considerable increment in filtration capacity from 1.7 to $6.9 \mathrm{~m}^{3} \mathrm{~m}^{-2} \mathrm{~d}^{-1}$ ( 3 to 14 times the water column a day) from March to August 1995.
\end{abstract}

KEY WORDS: Phytoplankton depletion - Benthic boundary layer - Temperature effect - Grazing impact · Phytoplankton control

\section{INTRODUCTION}

Shallow estuaries are often occupied by dense populations of benthic suspension feeders which have the potential to reduce phytoplankton biomass considerably (Cloern 1982, Nichols 1985). Several studies in coastal marine areas, with dense populations of bivalves (e.g. Jørgensen 1980, Sømod 1992), polychaetes (e.g. Davies et al. 1989, Riisgård 1991, Vedel et al. 1994), or ascidians (Petersen \& Riisgård 1992), have revealed that population filtration capacities often exceed the overlying water column volume several times a day. Insufficient vertical water mixing in the

•E-mail: vedel@dou.dk field, however, may uncouple the suspension feeders from the overlying water column, thereby preventing them from grazing on the phytoplankton (Loo \& Rosenberg 1989, Ott 1996). Rapid depletion of phytoplankton in the lower few centimetres above dense populations of suspension feeders may occur when vertical water mixing is limited (e.g. Wildish \& Kristmanson 1984, Frechette et al. 1989). Growth reduction has been reported in mussels Mytilus edulis situated in the algal depleted boundary layer, compared to mussels elevated $1 \mathrm{~m}$ above the bottom (Frechette \& Bourget 1985) and recently also in suspension-feeding polychaetes Nereis diversicolor kept in artificial burrows at different heights above the natural population (Riisgård et al. 1996b). 
The food depleted boundary layer above dense populations of suspension feeders, defined as the zone where food particles have been reduced to the lowest level which supports growth in the specific suspension feeder, may extend several centimetres from the suspension-feeding animals. Grazing experiments with ascidians Ciona intestinalis demonstrated that they were able to deplete phytoplankton in a zone of 20 to $30 \mathrm{~cm}$ from the colony (Riisgård et al. 1996a) and Nereis diversicolor has been reported to deplete a zone 5 to $10 \mathrm{~cm}$ from the bottom (Riisgård et al. 1996b). The extension of the algal depleted layer depends on external factors such as wind and wave generated turbulence and tidal currents, as well as the population filtration capacity and self generated water mixing created by water currents from the exhalant tubes or siphons. Detailed studies of the effect of siphonal currents, combined with horizontal tidal currents, have emphasized the importance of the siphonal currents in water mixing over bivalve beds (Monismith et al. 1990, O'Riordan et al. 1993, 1995). Increased bottom roughness caused by mussel beds (Butman et al. 1994) or polychaete tubes (Carey 1983) in combination with tidal currents may further enhance vertical water turbulence.

Annual and diurnal temperature changes may be extreme in shallow estuaries in temperate areas. Changes in temperature are known to give rise to immense differences of population grazing capacity in Nereis diversicolor (Vedel et al. 1994). The aim of the present study was to elucidate the effect of water temperature on phytoplankton depletion above dense populations of suspension-feeding $N$. diversicolor and to evaluate the impact of food depleted boundary layers on the ability of $N$. diversicolor populations to control phytoplankton biomass within the entire water column under natural conditions in the field.

\section{MATERIALS AND METHODS}

Study site. Grazing and suspension-feeding activity experiments were conducted from an investigation platform in the inner part of the shallow $(<1 \mathrm{~m}$ water depth) eutrophic Odense Fjord, Denmark (tidal amplitude $\sim 0.4 \mathrm{~m}, 11$ to $18 \% \mathrm{~S}$ ). A dense population of Nereis diversicolor (up to 3000 worms $\mathrm{m}^{-2}$ ) occupy the mud flats of the inner part of the fjord. Because of low salinity and a high sulfide content of the sediment, other benthic suspension feeders are excluded from the area or exist in very low numbers. (For locality map, see Vedel et al. 1994.)

Laboratory experiments. Set-up: Worms for phytoplankton grazing experiments were collected at the study site in December 1994. Experimental worms in the size class 250 to $540 \mathrm{mg}$ wet weight (40 to $85 \mathrm{mg}$ dry weight) were selected and weighed. Wet weight (WW) of Nereis diversicolor was converted to dry weight (DW) by the equation DW $=0.170+0.157 \mathrm{WW}$, according to Vedel \& Riisgård (1993). The worms were then brought to an insulated experimental tank (0.64 $\mathrm{m}^{2}$ bottom square area) containing 3851 of 18 to $21 \% \mathrm{~S}$ seawater $(60 \mathrm{~cm}$ water depth), with a $15 \mathrm{~cm}$ layer of sieved $(1 \mathrm{~mm}$ mesh size) sediment from the study site. The sediment was allowed to settle for $1 \mathrm{wk}$ before the addition of worms (mean individual weight $=71 \mathrm{mg}$ dry weight) to a density of $802 \mathrm{~m}^{-2}$. They were distributed uniformly in the sediment and acclimatized for $4 \mathrm{~d}$ at $15^{\circ} \mathrm{C}$. The worms were fed every second day with microalgae (10000 Rhodomonas sp. $\mathrm{m}^{-1}$ ) kept in suspension by means of air bubbling. The water was replaced once a week.

Cultivation of microalgae: Microalgae (Rhodomonâs sp., diameter $=6.2 \mu \mathrm{m}$ ) was cultivated in a $10 \mathrm{l}$ batch culture, $1.5 \times 10^{6}$ cells ml $\mathrm{m}^{-1}$ (light intensity $300 \mu \mathrm{E}$ $\mathrm{m}^{-2} \mathrm{~s}^{-1}$ ). One fourth of the culture was harvested every day and replaced with $20 \%$ seawater containing standard nutrient solution (Eriksen \& Iversen 1995). Algae numbers were determined with an electronic particle counter (Elzone-80xy, with a $76 \mu \mathrm{m}$ orifice tube).

Procedures: Grazing experiments were performed at different temperatures in the range from 5 to $20.5^{\circ} \mathrm{C}$. Water temperature was changed between single experiments at a rate of 0.5 to $6.0^{\circ} \mathrm{C} \mathrm{d}^{-1}$. Algae Rhodomonas sp. (10000 to 15000 cells $\left.\mathrm{ml}^{-1}\right)$ were added $1 \mathrm{~h}$ prior to grazing experiments to activate suspension feeding. Water aeration was used to create a homogenous suspension of algae. Aeration was discontinued at the start of the experiment $(t=0)$ in order to leave the water column undisturbed. At this time $(t=$ $0)$, water samples were collected at different heights above the sediment surface for measurements of water fluorescence by means of a water sampling device placed in the middle of the tank (Fig. 1). The samples were siphoned continuously through steel tubes (inner diameter $=2 \mathrm{~mm}$ ) extending different heights from the sediment surface $(0,2,4,6,8,10,12,16,20,24,28,32$, $36,40,44$ and $48 \mathrm{~cm}$ ). The samples $(10 \mathrm{ml})$ were collected in $10 \mathrm{ml}$ test tubes simultaneously from all heights, at a rate of $2 \mathrm{ml} \mathrm{min}{ }^{-1}$, by a peristaltic pump. The low sampling speed assured sampling of water from the specific water layers. Fluorescence was measured immediately after sampling, at 440 and $665 \mathrm{~nm}$, without any further treatment (Turner fluorometer, Model 450). Water sampling was continued until steady state, when only reduction of fluorescence due to sedimentation could be registered. The passive sedimentation rate in the mesocosm was tested in a single experiment ( $4 \mathrm{~h}$ ), after having isolated the water phase from the sediment with a sheet of plastic, following the 


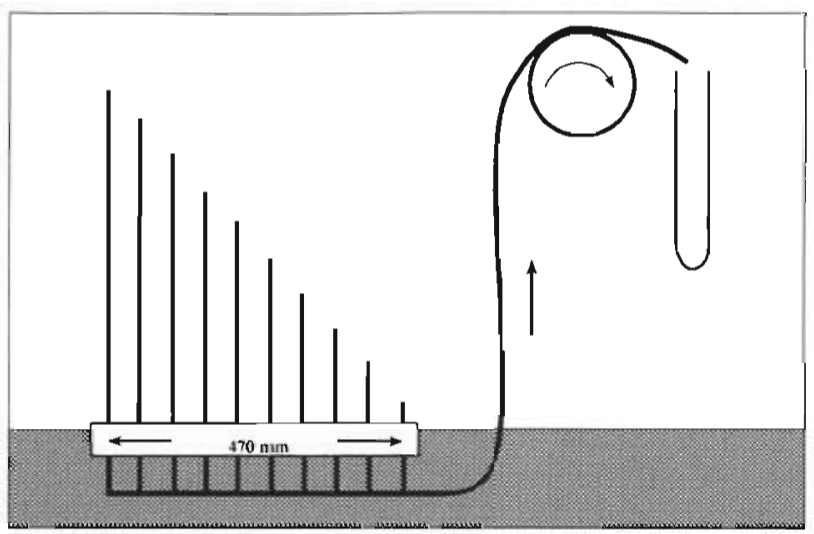

Fig. 1. Schematic illustration of water sampling device for vertical profiles. The distance between pairs of steel tubes was $50 \mathrm{~mm}$

measuring procedure above. Water fluorescence was converted to algal concentration by the correlation: $N=51.6 f-68.5$, where $f$ is fluorescence $(n=6$ measurements, range 2800 to 25000 cells $\mathrm{ml}^{-1}$ ).

Suspension-feeding activity: The suspension-feeding activity was recorded during the grazing experiment by means of the phototransducer system described by Vedel et al. (1994). A group of 8 worms was tested simultaneously at a height of $48 \mathrm{~cm}$ above the sediment surface to monitor the pumping activity at the various experimental temperatures. Each worm inhabited a U-shaped glass tube equipped with phototransducers which detected the movements of the worm. When the worms suspension feed, they pump water vigorously through the glass tube by undulatory body movements and the phototransducers were calibrated to count only these movements and neglect minor pumping or other activities. The pumping activity during suspension feeding is recognized as pumping periods of typically 5 to $10 \mathrm{~min}$ followed by a short interval with no activity when the worm ingests the net with captured food particles. The undulating body movements of the pumping worms were recorded as pumping strokes per minute and presented as a function of temperature.

Field experiments. Filtration activity and grazing impact were monitored during 6 field investigations in Odense Fjord (March to August 1995). The measurements were undertaken from a platform at a mean water depth of $0.5 \mathrm{~m}$. Filtration activity was monitored continuously for 1 to $2.5 \mathrm{~d}$ on 8 worms from the field site, using the phototransducer technique described above. The worms were placed in U-shaped glass tubes placed upright in the sediment, with the tube ends extending $1 \mathrm{~cm}$ above the bottom to allow the worms to suspension feed as well as surface deposit feed. Surface water chlorophyll a (chl a), temperature and wind speed were measured concurrently with the activity measurements every 1 to $3 \mathrm{~h}$. Water samples for chl a measurements $(0.5$ to $1.5 \mathrm{l})$ were filtered through $\mathrm{GF} / \mathrm{C}$ filters and the filters were extracted in $10 \mathrm{ml} 96 \%$ ethanol and kept dark at $5{ }^{\circ} \mathrm{C}$ overnight. The extract was then centrifuged at $3000 \mathrm{rpm}(1348 \times$ $g)$ for $10 \mathrm{~min}$ and the supernatant analysed spectrophotometrically at 665 and $750 \mathrm{~nm}$ (Shimadzu, UV1201 spectrophotometer) according to standard procedures of Jespersen \& Christoffersen (1987). Wind speed was measured at a nearby airport.

Vertical profiles of fluorescence were measured simultaneously with the filtration activity during the monitoring periods in April, May and July. Water was sampled at different heights above the bottom $(0,2,4$, $6,8,10,12,16,20,24,28,32,36,40,44$ and $48 \mathrm{~cm}$ ) for fluorescence measurements as described above (Fig. 1). These samples were preserved by adding $5 \mathrm{ml}$ of $96 \%$ ethanol to $5 \mathrm{ml}$ of water sample and kept in the dark until fluorescence was measured within $8 \mathrm{~h}$ of sampling. Before measurements, the samples were mixed to resuspend the algae. Wind speed, water temperature and surface water chl a were measured parallel to the fluorescence sampling as described above.

Worm population: The population biomass and density was estimated during each field experiment. Six randomly chosen sediment cores $\left(95 \mathrm{~cm}^{2}, 25 \mathrm{~cm}\right.$ deep) were collected and sieved (1 $\mathrm{mm}$ mesh size). Worms retained were counted and weighed individually after draining for 2 min on filter-paper.

\section{RESULTS}

\section{Laboratory experiments}

The mesocosm experiments demonstrated that the thickness of the algal depleted layers above populations of suspension-feeding Nereis diversicolor was highly dependent on water temperature (Figs. $2 \& 3 \mathrm{~A}$ ). After cessation of water mixing at $t=0$, the worms gradually depleted the phytoplankton within the boundary layer until a minimum of ca 2000 Rhodomonas sp. cells $\mathrm{ml}^{-1}$ was reached, within 2 to $3 \frac{3}{4} \mathrm{~h}$ (Fig. 2A-C). The height of the algal depleted layer at each temperature did not increase with time. The reduction in phytoplankton due to sedimentation was only $5 \%$ within $4 \mathrm{~h}$ and no change of the vertical profile was evident.

The height of phytoplankton depleted water layers was linearly related to water temperature with a slope of 1.22 in the range from 7 to $20.5^{\circ} \mathrm{C}$ (Fig. 3A). An almost identical temperature dependence of pumping activity was observed for Nereis diversicolor, inhabiting U-shaped glass tubes (Fig. 3B). Accordingly, the 

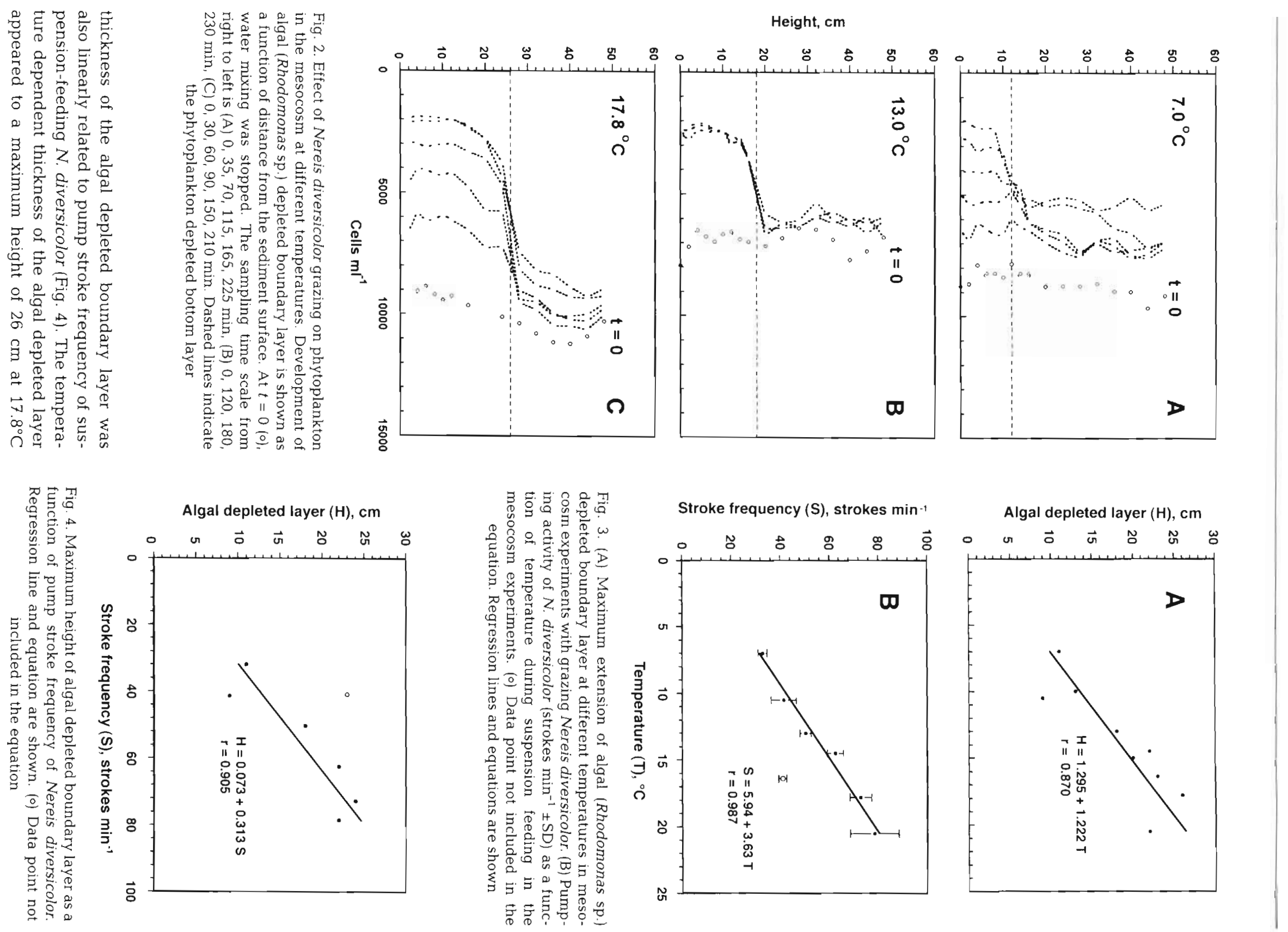
Table 1. Filter-feeding activity, estimated population filtration capacities, density and biomass of Nereis diversicolor in Odense Fjord, Denmark. Surface water chlorophyll a and temperature \pm SD were measured every 1 to $3 \mathrm{~h}$. Numbers in parentheses denote sample numbers. Vertical profiles were measured parallel to activity measurements on April 12, May 30 and July 6, 1995

\begin{tabular}{|c|c|c|c|c|c|c|c|c|}
\hline Date & $\begin{array}{l}\text { Duration } \\
\text { (d) }\end{array}$ & $\begin{array}{c}\text { Worms } \\
\text { (ind.) }\end{array}$ & $\begin{array}{c}\text { Activity } \\
(\% \text { of time) }\end{array}$ & $\begin{array}{c}\text { Chlorophyll a } \\
\left(\mu \mathrm{g} \mathrm{l}^{-1}\right)\end{array}$ & $\begin{array}{l}\text { Temperature } \\
\qquad\left({ }^{\circ} \mathrm{C}\right)\end{array}$ & $\begin{array}{c}\text { Worm } \\
\text { density } \\
\text { (ind. } \mathrm{m}^{-2} \text { ) }\end{array}$ & $\begin{array}{l}\text { Worm } \\
\text { biomass } \\
\left(\mathrm{g} \mathrm{m}^{-2}\right)\end{array}$ & $\begin{array}{c}\text { Filtration } \\
\text { capacity } \\
\left(\mathrm{m}^{3} \mathrm{~m}^{-2} \mathrm{~d}^{-1}\right)\end{array}$ \\
\hline Mar 29-30 & 1.0 & 8 & 20.0 & $2.2 \pm 1.0$ & $4 \pm 2(18)$ & 1491 & 30.4 & 1.7 \\
\hline Apr 11-13 & 2.5 & 8 & 18.1 & $1.6 \pm 0.5(24)$ & $11 \pm 1$ & 1281 & 26.2 & 3.2 \\
\hline Apr 30-May 1 & 2.0 & 8 & 34.1 & $2.3 \pm 0.7$ & $15 \pm 3$ & - & - & 4.2 \\
\hline May $29-31$ & 2.5 & 5 & 25.8 & $4.2 \pm 0.9(28)$ & $18 \pm 1$ & 1526 & 25.1 & 4.4 \\
\hline Jul $5-7$ & 2.5 & 7 & 29.1 & $6.1 \pm 0.9(17)$ & $19 \pm 3(16)$ & 1810 & 27.0 & 4.6 \\
\hline Aug 1-3 & 2.5 & 8 & 43.4 & $21.4 \pm 5.6(20)$ & $24 \pm 3(14)$ & 1491 & 27.9 & 6.9 \\
\hline
\end{tabular}

(Fig. 3A). Algal depletion was not observed at the lowest experimental temperature, $5^{\circ} \mathrm{C}$, because of low suspension-feeding activity.

\section{Field experiments}

The population density and biomass at the field site was nearly constant during March to August (Table 1). The population filtration capacity however, increased from 1.7 to $6.9 \mathrm{~m}^{3} \mathrm{~m}^{-2} \mathrm{~d}^{-1}$ (3 to 14 times the water column per day) during the season due to a total temperature rise of $20^{\circ} \mathrm{C}$. Suspension-feeding activity of Nereis diversicolor occupied 18 to $43 \%$ of the total available feeding time during the 6 field studies (Table 1). An increasing percentage of time used for suspension feeding was observed with increasing water chl a. The worm population however, was not able to control a successively increasing phytoplankton bloom during the summer (Fig. 5, Table 1).

Nereid grazing reduced phytoplankton in the lower 4 to $8 \mathrm{~cm}$ above the bottom to 50 to $60 \%$ of the surface level in the field (Fig. 6). In April, when the filtration capacity was estimated to be $3.2 \mathrm{~m}^{3} \mathrm{~m}^{-2} \mathrm{~d}^{-1}$, and chl a concentration was low, no phytoplankton depleted layer developed (Fig. 6A). In May, at a population filtration capacity of $4.6 \mathrm{~m}^{3} \mathrm{~m}^{-2} \mathrm{~d}^{-1}$, an algal depleted layer developed up to $4 \mathrm{~cm}$ above the sediment surface, with fluorescence of about half the level in the surface water (Fig. 6B). A $40 \%$ reduction of surface water fluorescence was observed at the bottom in July at $21.5^{\circ} \mathrm{C}$. In July, the population filtration capacity increased from 3.6 to $5.2 \mathrm{~m}^{3} \mathrm{~m}^{-2} \mathrm{~d}^{-1}$ within $8 \mathrm{~h}$, due to an abrupt temperature rise from 14.5 to $21.5^{\circ} \mathrm{C}$, leading to an increased depletion from 25 to $40 \%$, but with no change in the thickness of the boundary layer (Fig. 6C). A wind speed of 6.2 to $8.2 \mathrm{~m} \mathrm{~s}^{-1}$ during the measurements in July did not generate sufficient water turbulence to prevent the formation of a phytoplankton depleted boundary layer up to $8 \mathrm{~cm}$ from the bottom.

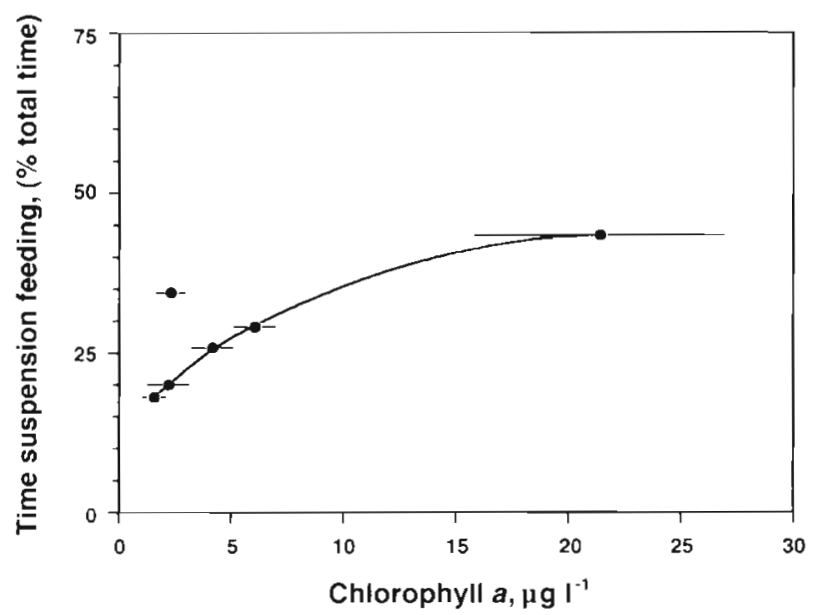

Fig. 5. Percent of Nereis diversicolor population suspensionfeeding in Odense Fjord, at different chlorophyll a levels $\pm \mathrm{SD}$, during 1995 (March to August)

\section{DISCUSSION}

\section{Laboratory experiments}

Nereis diversicolor had a pronounced effect on phytoplankton concentration in the boundary layer (Fig. 2). It was demonstrated that the ability of the worms to deplete the boundary layer for phytoplankton was highly correlated with temperature and thus the filtration and water pumping activity (Fig. 3A, B). At the optimum temperature of $17.8^{\circ} \mathrm{C}$, the worm population was able to deplete the water column of phytoplankton to the height of $26 \mathrm{~cm}$ in undisturbed water (Fig. 3A).

The thickness of the algal depleted layer was controlled by a combination of clearance capacity of the worms and the strength of vertical water mixing generated by the water jets ejected from the worm 

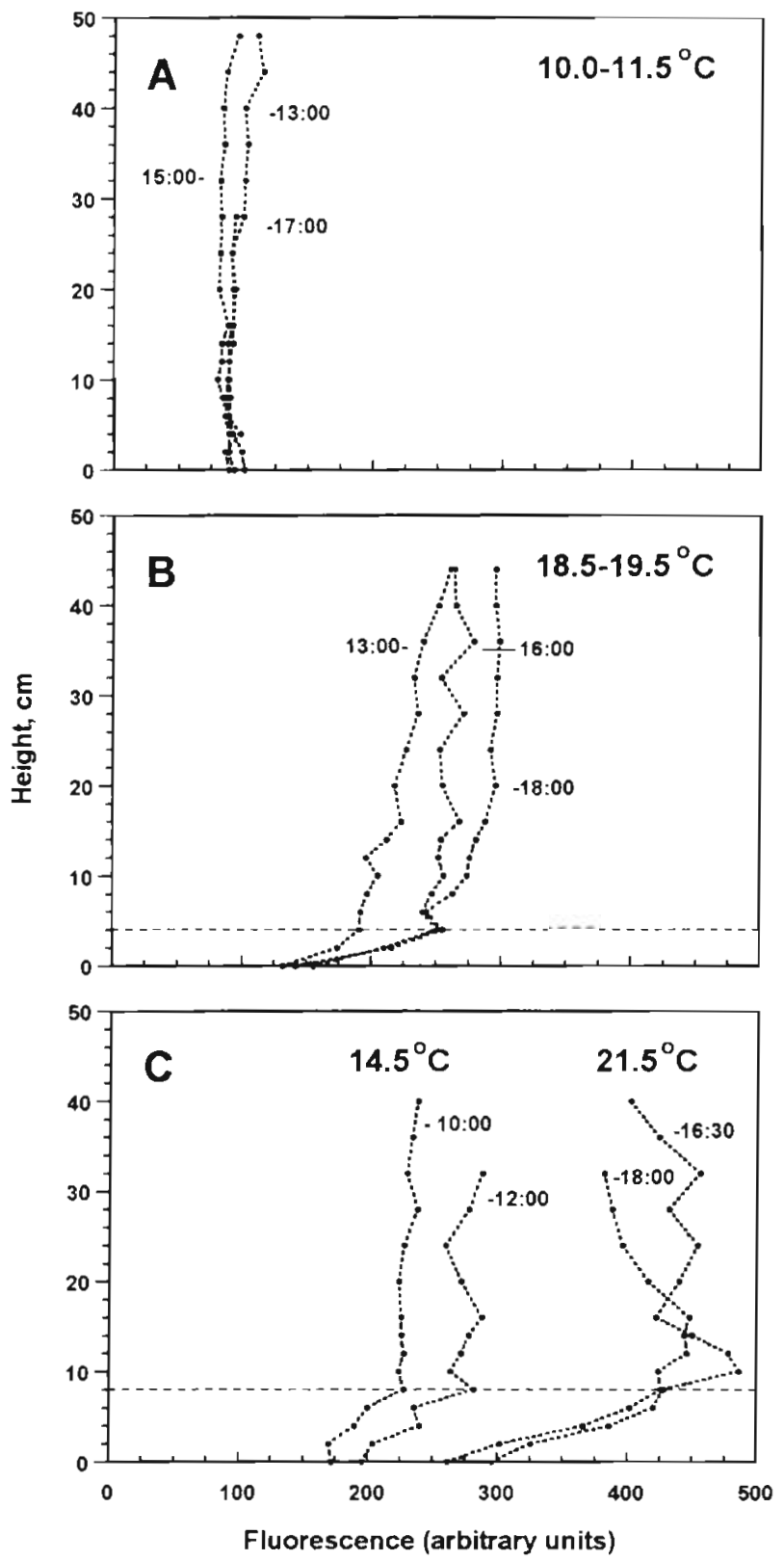

Fig. 6. Grazing effect of Nereis diversicolor in Odense Fjord, 1995. Vertical profiles are shown at different temperatures and time of day. Dashed lines indicate the phytoplankton depleted boundary layer. (A) April 12, surface water chl $a=$ 1.2 to $1.5 \mathrm{\mu g} \mathrm{l}^{-1}$, wind speed $=2.6$ to $5.1 \mathrm{~m} \mathrm{~s}^{-1}$. (B) May 30 , chl $a=2.1$ to $3.1 \mathrm{\mu g} \mathrm{l}^{-1}$, wind speed $=2.6$ to $5.1 \mathrm{~m} \mathrm{~s}^{-1}$. (C) July

6 , chl $a=5.3$ to $6.0 \mu \mathrm{g} \mathrm{l}^{-1}$, wind speed $=6.2$ to $8.2 \mathrm{~m} \mathrm{~s}^{-1}$

tubes. After some days of exposure to suspended phytoplankton, small chimney-like structures extruded from the worm burrows in the mesocosm. The structures are presumably identical to the narrow mucus siphons (diameter $-2.5 \mathrm{~mm}$ ) which are often observed at the excurrent burrow opening of artifi- cial burrows (U-shaped glass tubes), through which the phytoplankton cleared water is ejected with higher speed. According to Riisgård (1991), a mean size worm (450 mg) can pump up to $10 \mathrm{ml} \mathrm{min}^{-1}$ at $17^{\circ} \mathrm{C}$. Based on the temperature dependent stroke frequency (Fig. 3B), water speed through the exhalant siphon may increase linearly from 1.4 to $4.1 \mathrm{~cm}$ $\mathrm{s}^{-1}$ in the temperature range 5 to $20.5^{\circ} \mathrm{C}$, resulting in a vertical mixing of the algal depleted layer. The constant height of the phytoplankton depleted zone through time, at each temperature, was likely a consequence of a constant height of the vertically mixed zone due to the water jets from the worm tubes. A fast grazing rate in this vertically mixed water layer ensured the integrity of the vertical phytoplankton profiles (Fig. 2). The model of Riisgård et al. (1996b), on the other hand, predicted a gradual height increment of the algal depleted layer above a suspensionfeeding population of Nereis diversicolor within the first hours after onset of water mixing. This model applies for the situations where diffusive forces dominate the boundary layer formation. The importance of exhalant siphonal currents for mixing of the near bottom water and extension of algal depleted water layers above suspension-feeding bivalves has previously been investigated and emphasized by several authors (e.g. Monismith et al. 1990, O'Riordan et al. 1993, 1995).

In contrast to the present study, Riisgård et al. (1996b) found no temperature dependent changes in the thickness of the algal depleted layer in the presence of suspension-feeding Nereis diversicolor populations. However, the worm density in their experiments was much lower (120 to 186 worms $\mathrm{m}^{-2}$ ) than here $\left(802 \mathrm{~m}^{-2}\right)$, resulting in a much less extended boundary layer ( 2 to $5 \mathrm{~cm}$ ). The filtration capacity of the worm population in the mesocosm is roughly 200 to $600 \mathrm{l} \mathrm{m}^{-2} \mathrm{~h}^{-1}$ over the temperature range from 5 to $20.5^{\circ} \mathrm{C}$. Based on these numbers, the half-life of phytoplankton in a completely mixed boundary layer is approximately $T_{1 / 2}^{1 / 2}=0.5 \mathrm{~h}$ at both $7^{\circ} \mathrm{C}(12 \mathrm{~cm}$ height of algal depletion) and $17.8^{\circ} \mathrm{C}(18 \mathrm{~cm}$ height $)$. However, the observed half-lives were approximately $2 \mathrm{~h}\left(7^{\circ} \mathrm{C}\right)$ and $1 \mathrm{~h}\left(17.8^{\circ} \mathrm{C}\right)$ respectively, indicating that vertical mixing was relatively slow and that the algal depleted water of the boundary layer was refiltered repeatedly, resulting in longer half-life of the phytoplankton. The algal concentration in the boundary layer was reduced to a minimum of 1500 to 3000 cells $\mathrm{ml}^{-1}$ within 2 to $3 \frac{3}{4}$ h (Fig. 2). At this concentration, filtration usually ceases because suspension feeding is no longer profitable (Vedel \& Riisgård 1993, Nielsen et al. 1995). Similar reduction of phytoplankton was observed above a population of ascidians Ciona intestinalis by Riisgård et al. (1996a). 


\section{Field study}

Estimates of worm population filtration capacity in Odense Fjord (March to August) ranged between 1.7 and $6.9 \mathrm{~m}^{3} \mathrm{~m}^{-2} \mathrm{~d}^{-1}$. This corresponds to a turnover of the whole water column 3 to 14 times a day, at a mean water depth of $0.5 \mathrm{~m}$. However, the filtration capacity of the worm population was probably not fully reached due to frequent phytoplankton depletion of the boundary layer. The formation of a phytoplankton depleted boundary layer was evident whenever sufficient phytoplankton was present in the overlying water column. In April, the water chl a was low (1.2 to $1.5 \mu \mathrm{g}$ chl $a^{-1}$ ) and hardly enough to trigger suspensionfeeding in Nereis diversicolor (lower limit at 1 to $3 \mu \mathrm{g}$ chl a $\mathrm{l}^{-1}$; Vedel et al. 1994). Consequently, no phytoplankton depleted boundary layer was likely to occur at this phytoplankton level. The surface water chl $a$ in

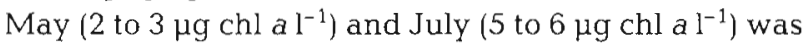
above the trigger level and could support growth of $N$. diversicolor (Vedel \& Riisgård 1993, Vedel et al. 1994). However, nereid grazing reduced phytoplankton in the lower 4 to $8 \mathrm{~cm}$ above the bottom to $50-60 \%$ of the surface level. This resulted in boundary layer concentrations in May and July, which was close to the trigger level ( 1 to $3 \mu \mathrm{g} \mathrm{chl} \mathrm{a} \mathrm{l}^{-1}$ ) for suspension feeding, mentioned above. In the natural shallow habitats of $N$. diversicolor, considerable seasonal and diurnal temperature variation can influence the filtration capacity and ability to deplete phytoplankton markedly. Previous field studies by Vedel et al. (1994) have shown that the instant linear relation between temperature and pumping activity found in the present laboratory experiments also applies for gradual temperature changes during the season. An example of a naturally occurring diurnal temperature change is observed in July, where the temperature rose from 14.5 to $21.5^{\circ} \mathrm{C}$ within $8 \mathrm{~h}$, leading to a $\sim 44 \%$ increase of filtration capacity and an increased depletion of phytoplankton in the boundary layer (Fig. 6C).

\section{Ecological implications}

A considerable increase of surface water chl a developed during 1995 (Fig. 5). This indicates that the worm population could not control the phytoplankton level in the field despite a considerable increase in filtration capacity (from 3 to 14 times the water column a day) from March to August (Table 1). Laboratory and field experiments have shown that Nereis diversicolor may suspension feed for more than $50 \%$ of time, when sufficient phytoplankton is available (Vedel et al. unpubl.). The relatively low suspension-feeding activity in the present field studies during periods of high chl $a$ in the surface water must be a result of phytoplankton depletion in the near bottom water, combined with the switching of $N$. diversicolor from suspension-feeding to surface deposit-feeding. The relatively low filtration activity found by Vedel et al. (1994) at chl a concentra-

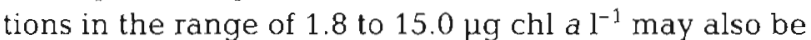
explained by phytoplankton depletion near the bottom. Food limited growth in filter-feeding $N$. diversicolor has been reported by Riisgård et al. (1996b) in the shallow Kertinge Nor, Denmark (worm biomass $=52 \mathrm{~g}$ dry wt $\mathrm{m}^{-2}$ ), where high growth rates $\left(\mu=2\right.$ to $\left.2.5 \% \mathrm{~d}^{-1}\right)$ were obtained in worms inhabiting in glass tubes elevated 10 to $20 \mathrm{~cm}$ above the bottom, compared to worms $(\mu=0.2$ to $1.4 \% \mathrm{~d}^{-1}$ ) situated within the phytoplankton depleted boundary layer 0 and $4 \mathrm{~cm}$ from the bottom. Similar growth improvements have been observed in blue mussels Mytilus edulis elevated $1 \mathrm{~m}$ above the bottom (Fréchette \& Bourget 1985).

The extension of the phytoplankton depleted boundary layer in the field depends on external factors, such as wind and wave generated turbulence and tidal currents. Vertical profiles of tidal currents are not available in the present study, but previous studies have shown that the exhalant water jets from mussel siphons are deflected by horizontal water currents (Monismith et al. 1990, O'Riordan et al. 1993, 1995). As a result, the height of the zone affected by the vertical water jets is reduced with increasing velocity of horizontal currents. This might explain the reduced height of the phytoplankton depleted layer in the field compared to the mesocosm study, together with the fact that worm biomass was approximately twice as high in the mesocosm.

Wind driven wave action is considered to be the main cause of vertical mixing of the water column in shallow areas with low tidal amplitude (e.g. Sanford 1994, Pedersen et al. 1995, Schoellhamer 1995). In the present field study, wind speeds of 6.2 to $8.2 \mathrm{~m} \mathrm{~s}^{-1}$ during the measurement in July were not sufficient to break the stratification of the water column. A pronounced algal depletion was observed up to $8 \mathrm{~cm}$ above the bottom at this wind speed. Measurements of wind speeds revealed that the wind speed was below $8 \mathrm{~m} \mathrm{~s}^{-1} \sim 70 \%$ of the year 1995 (March to August). This indicates that the situation of algal depletion near the bottom may have been the prevailing situation at the field site in Odense Fjord in 1995.

Acknowledgements. Thanks are due to Dr Erik Kristensen and Dr Colin Brauner for helpful discussions and for critically reading this paper. Thanks are also due to the anonymous reviewers, and to the Danish Meteorological Institute for information concerning wind data. The investigations were conducted as a part of the Danish Environmental Research Programme 1922 to 1996, Centre for Strategic Environmental Research in Marine Areas. 


\section{LITERATURE CITED}

Butman CA, Frechette M, Geyer WR, Starczak VR (1994) Flume experiments on food-supply to the blue mussel Mytilus edulis L. as a function of boundary-layer flow. Limnol Oceanogr 39:1755-1768

Carey DA (1983) Particle resuspension in the benthic boundary layer induced by flow around polychaete tubes. Can J Fish Aquat Sci 40:301-340

Cloern JE (1982) Does the benthos control phytoplankton biomass in South San Francisco Bay? Mar Ecol Prog Ser 9: $191-202$

Davies BR, Stuart V, de Villiers M (1989) The filtration activity of a serpulid polychaete population (Ficopomatus enigmaticus (Fauvel)) and its effects on water quality in a coastal marina. Estuar Coast Shelf Sci 29:613-620

Eriksen TN, Iversen JJL (1995) On-line determination of pigment composition and biomass in cultures of microalgae. Biotechnol Tech 9:49-54

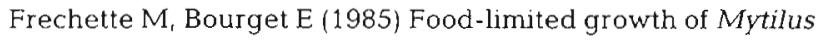
edulis $\mathrm{L}$. in relation to the benthic boundary layer. Can J Fish Aquat Sci 42:1166-1170

Frechette M, Butman CA, Geyer WR (1989) The importance of boundary-layer flows in supplying phytoplankton to the benthic suspension feeder, Mytilus edulis L. Limnol Oceanogr 34:19-36

Jespersen AM, Christoffersen K (1987) Measurements of chlorophyll a from plankton using ethanol as extracting solvent. Arch Microbiol 109:445-454

Jørgensen BB (1980) Seasonal oxygen depletion in the bottom waters of a Danish fjord and its effect on the benthic community. Oikos 34:68-76

Loo LO, Rosenberg R (1989) Bivalve suspension-feeding dynamics and benthic-pelagic coupling in an eutrophicated marine bay. J Exp Mar Biol Ecol 130:253-276

Monismith SG, Koseff JR, Thompson JK, O'Riordan CA, Nepf HM (1990) A study of model bivalve siphonal currents. Limnol Oceanogr 35:680-696

Nichols FH (1985) Increased benthic grazing: alternative explanation for low phytoplankton biomass in northern San Francisco Bay during the 1976-1977 drought. Estuar Coast Shelf Sci 21:379-388

Nielsen MA, Eriksen TN, Iversen JJL, Riisgård HU (1995) Feeding, growth and respiration in the polychaetes Nereis diversicolor (facultative filter-feeder) and $N$. virens

Editorial responsibility: Otto Kinne (Editor),

Oldendorf/Luhe, Germany (omnivorous) - a comparative study. Mar Ecol Prog Ser 125:149-158

O'Riordan CA, Monismith SG, Koseff JR (1993) A study of concentration boundary-layer formation over a bed of model bivalves. Limnol Oceanogr 38:1712-1729

O'Riordan CA, Monismith SG, Koseff JR (1995) The effect of bivalve excurrent jet dynamics on mass-transfer in a benthic boundary-layer. Limnol Oceanogr 40:330-344

Ott JA (1996) The Adriatic benthos: problems and perspectives. Marine eutrophication and population dynamics. 25th European Marine Symposium. Olsen \& Olsen, Fredensborg

Pedersen OB, Christiansen C, Laursen B (1995) Wind-induced long term increase and short term fluctuations of shallow water suspended matter and nutrient concentrations, Ringkøbing Fjord, Denmark. Ophelia 41:273-287

Petersen JK, Riisgård HU (1992) Filtration capacity of the ascidian Ciona intestinalis and its grazing impact in a shallow fjord. Mar Ecol Prog Ser 88:9-17

Riisgård HU (1991) Suspension feeding in the polychaete Nereis diversicolor. Mar Ecol Prog Ser 70:29-37

Riisgård HU, Jürgensen C, Clausen T (1996a) Filter-feeding ascidians (Ciona intestinalis) in a shallow cove-implications of hydrodynamics for grazing impact. J Sea Res 35:293-300

Riisgård HU, Poulsen L, Larsen PS (1996b) Phytoplankton reduction in near-bottom water caused by filter-feeding Nereis diversicolor -implications for worm growth and population grazing impact. Mar Ecol Prog Ser 141:47-54

Sanford LP (1994) Wave-forced resuspension of upper Chesapeake Bay muds. Estuaries 17:148-165

Schoellhamer DH (1995) Sediment resuspension mechanisms in Old Tampa Bay, Florida. Estuar Coast Shelf Sci 40:603-620

Sømod B (1992) Production, assimilation and pump capacities of common mussel in Mariager Fjord. Miljøkontoret Århus county, Denmark

Vedel $A_{1}$ Andersen BA, Riisgård HU (1994) Field investiga. tions of pumping activity of the facultatively filter-feeding polychaete Nereis diversicolor using an improved infrared phototransducer system. Mar Ecol Prog Ser 103:91-101

Vedel A, Riisgård HU (1993) Filter-feeding in the polychaete Nereis diversicolor: growth and bioenergetics. Mar Ecol Prog Ser 100:145-152

Wildish DJ, Kristmanson DD (1984) Importance to mussel of the benthic boundary layer. Can J Fish Aquat Sci 741 $1618-1625$

Submitted: August 25, 1997; Accepted: November 17, 1997 Proofs received from author(s): February 18, 1998 